\title{
DIFFERENCES IN THE ANTHROPOLOGICAL PROFILE OF THE BASKETBALL REFEREES WITH REGARDS TO THEIR CHRONOLOGICAL AGE
}

\author{
Tomislav Rupčić ${ }^{1}$, Bojan Matković ${ }^{1}$, Damir Knjaz ${ }^{1}$, Saša Baščevan ${ }^{2}$, and Saša Rodić ${ }^{3}$ \\ ${ }^{1}$ Faculty of Kinesiology, Zagreb, Croatia \\ ${ }^{2}$ Polyclinic "Petand", Zagreb, Croatia \\ ${ }^{3}$ High School Jastrebarsko, Zagreb, Croatia
}

ORIGINAL SCIENTIFIC PAPER

DOI: 10.5550/sgia.110701.en.027R

COBISS.BH-ID: 2102040

UDC: 796.323 .072 .4

\section{SUMMARY}

The aim of our research was to determine differences in the anthropological profile of best Croatian basketball referees with regard to their chronological age. The study included 31 referees from the A referee list in the competitive season 2008/2009. In order to determine the statistical differences they were divided into two age groups; young $(n=16)$ including referees age 26-32 and older group $(n=15)$ including referees aged 33-46. Participants were tested on different variables for the assessment of motor and functional abilities and morphological characteristics. Also, in this research were included two variables called Quality of officiating and Experience. Data analysis was performed using the software package STATISTICA for Windows, $8^{\text {th }}$ version. For each variable basic descriptive statistical parameter was calculated. Analysis of statistical differences in the anthropological profile with regard to the chronological age of basketball referees was performed using $t$-test for independent samples. According to our results basketball referees differ only in the variables for the assessment of motor abilities, while there were no statistically significant differences in the tested morphological characteristics and functional abilities regarding referees' age. To conclude, investigated basketball referees were all well physically prepared, meeting high standards of physical conditioning-motor preparation needed for the basketball games of the highest national level.

Key Words: basketball, referees, chronological age, anthropological profile, experience.

\section{INTRODUCTION}

Basketball is a very complex and dynamic sporting activity characterized by rapid and frequent changes of offensive and defensive actions. Generally, basketball falls into a group of complex sports that are composed of simple and complex motion in terms of cooperation between teammates during the game. Modern basketball is characterized by high intensity activity during all forty minutes of the game, which requires a players' excellent fitness - motor preparation (Matković \& Matković, 2010).

As well as players, basketball referees are also an integral part of basketball, and their role in the final outcome is very important, sometimes even crucial. Especially, having in mind the statistics that show how $90 \%$ of basketball games on any competing level end with one to three points more or less in favor of one or the other team.
Quality fitness - motor preparation of the referees allows them better tracking of players dynamic movement during the game, which results in better quality of officiating and positively reflects on regularity of basketball competitions, which in the end affects on positive development of basketball as a sports game.

\section{METHODS}

\section{Sample of respondents}

The sample of respondents consisted of 31 basketball referees from the A referee list for the season 2008/2009. The list of referees was determined by The Croatian Basketball Referees Association, and is compiled every year according to officiating performance of the referees in the previous season.

For the purpose of determining differences in anthropological profile of basketball referees according to their chronological age, the sample of respon- 
dents was combined into two subsamples. One subsample (Young; $n=16$ ) was combined of the referees aged 26 to 32 years (29.62 \pm 1.85 years), and the other (Older, $n=15)$ included referees from 33 to 46 years of age ( $37.33 \pm 4.56$ years).

\section{Variable sample}

Variable sample was composed of morphological characteristics, tests for evaluating motor and functional abilities and two variables called Quality of officiating and Experience. Measured morphological characteristics were: height, body mass and fat percentage (bioelectric impedance) and body mass index was also calculated. Motor tests - eight with bending (MAGOSM), 4x5 meters (MAG4x5), side steps (MAGKUS), and 93639 with a turn (MAG9OK), were used to estimate agility, while a test -20 meter run with lap time at 5 and 10 meters (MES20M, MESP05 i MESP10), was used to estimate explosive power sprint type. All motor tests used in the research are well known and have quality metric characteristics (Jukić, Vučetić, Aračić, Bok, Dizdar, Sporiš et al., 2008; Metikoš, Prot, Horvat, Kuleš, \& Hoffman, 1982). With the use of maximal ergometry test on the treadmill, maximum oxygen intake was measured and ventilatory threshold was determined. Measuring instruments (Cosmed - Quark b ${ }^{2}$ "breath by breath" spiroegometer, a Technogym - Runrace Competition
HC1200 treadmill and a telemetry heart rate monitor - Polar Electro OY CE 0537) that were used, provide direct, "on-line" monitoring and the analysis of ventilation metabolic parameters, while the high reliability of measured data is increased by the constant microclimatic conditions in the lab.

First variable - quality of officiating - tells us about successful officiating of a certain referee in the previous season. It makes a grade point average obtained by controllers of officiating during basketball games. Second variable - experience - tells us about the number of competitive seasons which a certain referee has officiated in the highest national ranking competition.

\section{Data processing methods}

Data processing was conducted with the use of a software package STATISTICA for Windows, version 8. For each variable the following parameters were calculated: mean $(M)$, standard deviation $(S D)$, minimum value $(M I N)$, maximum value $(M A X)$, range of scores $(R A N)$, kurtosis (KURT), and skeweness $(S K E W)$. The testing of statistical differences in anthropological profile considering the chronological age of the basketball referees was done with the use of $t$-test on independent samples.

\section{TABLE 1}

Descriptive statistical parameters of referees' morphological characteristics

\begin{tabular}{lcrrrrr}
\hline \multicolumn{1}{c}{$n=31$} & $M$ & $S D$ & $M I N$ & $M A X$ & $\max D$ & K-Sp \\
\hline Height $(\mathrm{cm})$ & 186.34 & 5.40 & 176.40 & 198.50 & .083 & .984 \\
\hline Mass $(\mathrm{kg})$ & 88.04 & 7.47 & 74.80 & 107.00 & .104 & .891 \\
\hline \%fat $(\%)$ & 15.99 & 3.37 & 8.20 & 23.40 & .095 & .945 \\
\hline BMI $\left(\mathrm{kg} / \mathrm{m}^{2}\right)$ & 25.32 & 1.60 & 21.80 & 29.20 & .095 & .945 \\
\hline
\end{tabular}

Legend: $M$ - mean; $S D$ - standard deviation; $M I N$ - minimum value; $M A X$ - maximum value; $\max D$ - maximum distance between the theoretical cumulative relative frequency (normal) and the relative cumulative empirical frequency (obtained by measurement); $K-S p$ - error of statistical inference; Height $(\mathrm{cm})$ - body height; Mass $(\mathbf{k g})$ - body weight; $\%$ fat - body fat percentage; BMI $\left(\mathbf{k g} / \mathbf{m}^{2}\right)$ - body mass index.

\section{RESULTS AND DISCUSSION}

Table 1 shows descriptive statistical parameters of morphological characteristics of the basketball referees. Based on the results it can be concluded that with their height, the basketball referees significantly exceed the average population of adult men in Croatia (Mišigoj-Duraković, Heimer, \& Matković, 1998; Ružić,
Heimer, Mišigoj-Duraković, \& Matković, 2003). Surely, it is related to the selection that is done in the youngest age in basketball, where height has an important role in selection of beginner boys. Since most of the referees had their first experience with the game of basketball as players, and only afterwards choose officiating as a form of participation in this interesting and demanding sport, it isn't surprising 
that they are tall on average. Body mass is consistent with height. One thing that is probably more interesting and is related to morphological characteristics, and has probably more influence on game officiating efficiency, is body composition which was determined in two ways: by measuring the amount of body fat with bioelectrical impedance procedure and calculating the body mass index. According to the classification of the World Health Organization (Lewis, McTigue, Burke, Poirier, Eckel, Howard et al., 2009) which helps us determine nutrition degree, and with the obtained average body mass index $(25.32 \pm 1.60 \mathrm{~kg} /$ $\mathrm{m}^{2}$ ), it can be concluded that the referees belong to the group of people with slightly increased body mass (from 25.00 to $29.92 \mathrm{~kg} / \mathrm{m}^{2}$ ). From the total number of respondents, 14 referees fall into the group with normal body mass index, while even 17 of them have the BMI between 25.0 and $29.9 \mathrm{~kg} / \mathrm{m}^{2}$, which means that these values put them into the group of people with excessive body weight.

However, the obtained average amount of body fat, expressed in percentage $(15.99 \pm 3.37 \%)$, tells us that the referees belong to a group of people with optimal body composition (Wilmore, Costill, \& Kenney, 2008). Reason for such different interpretation regarding determination of body composition, should be sought in the manner of calculating the body mass index. BMI is calculated as the ratio between body weight $(\mathrm{kg})$ and the square of body height $\left(\mathrm{m}^{2}\right)$, and based on its value, a body composition can't actually be determined with certainty. Also, very often happens that two people with the same body weight and height have a different body composition or a different proportion of body fat and lean body mass.
Table 2 shows that "younger" referees (26-32 years) have the average height of $187.63 \mathrm{~cm}$, and body weight of $88.03 \mathrm{~kg}$. The percentage of body fat is $15.63 \%$, and the body mass index is $25.03 \mathrm{~kg} / \mathrm{m}^{2}$. Basketball referees who, by their chronological age, fall into the sample of "older" respondents (33-46 years), have the average height of $184.98 \mathrm{~cm}$, and body weight of $88.06 \mathrm{~kg}$. The percentage of their body fat is $16.37 \%$, and the body mass index is $25.63 \mathrm{~kg} / \mathrm{m}^{2}$.

The results of the $t$-test for independent samples between the two subsamples of respondents show that statistically significant differences in morphological characteristics between younger and older basketball referees do not exist. Based on the value of body fat percentage, it can be concluded that both younger and older referees fall into a group of people with optimal body composition (Wilmore et al., 2008).

Previous studies conducted on basketball referees weren't able to establish which of the motor abilities are responsible for successful monitoring and efficient movement of the referees during the game.

Knowing the dynamic of the game, type of rotation of the referees during the game (three - person mechanics of officiating), and the need to find the ideal angle of observation of a certain situation on the court, it can be assumed that explosive power sprint type and agility have the greatest predictive value of motor abilities for successful officiating (Rupčić, Matković, \& Knjaz, 2010).

For this reason, for the purposes of this research were selected tests of valid metric characteristics to estimate agility - motor ability which is largely responsible for conducting quick changes of direction and explosive power sprint type.

\section{TABLE 2}

T-test on independent samples - morphological characteristics

\begin{tabular}{lrrrrrr}
\hline \multicolumn{1}{c}{ Variables } & $\begin{array}{c}M(26-32) \\
\text { Younger }\end{array}$ & $\begin{array}{c}M(33-46) \\
\text { Older }\end{array}$ & $t$-value & $d f$ & $p$ & F-ratio \\
\hline Height $(\mathrm{cm})$ & 187.63 & 184.98 & -1.38500 & 29 & .176 & 1.140386 \\
\hline Mass $(\mathrm{kg})$ & 88.03 & 88.06 & .01052 & 29 & .991 & 2.088158 \\
\hline \% fat $(\%)$ & 15.63 & 16.37 & .60013 & 29 & .553 & 1.517649 \\
\hline BMI $\left(\mathrm{kg} / \mathrm{m}^{2}\right)$ & 25.03 & 25.63 & 1.03193 & 29 & .310 & 1.071882 \\
\hline
\end{tabular}

Legend: Height (cm) - body height; Mass (kg) - body weight; \%fat - body fat percentage; BMI $\left(\mathrm{kg} / \mathrm{m}^{2}\right)$ - body mass index; $M$ - mean; $d f$ - degrees of freedom; $p$ - statistical significance.

In the test Side steps (MAGKUS), used to estimate lateral agility movements, the basketball referees reached an average value of $8.19 \pm 0.82$ seconds, with the range of scores from 6.54 to 9.90 seconds, which is slightly worse in comparison to the results in the same test of the professional basketball players 
(Matković \& Matković, 2010). However, considering a few best results achieved on the test, it can be seen that some of the referees have achieved better values than the players' average.

Comparing the obtained results in the test 20 meter run with lap time at 5 and 10 meters (MESP05: 1.54 \pm 0.15 seconds, MESP10: $2.37 \pm 0.18$ seconds and MES20M: $3.78 \pm 0.24$ seconds) with achieved results of the professional players (MESP05: $1.31 \pm 0.17$ seconds, MESP10: $2.05 \pm 0.22$ seconds and MES20M: $3.33 \pm 0.26$ seconds, SDC Faculty of Kinesiology University of Zagreb), and also the values obtained by extensive research on a sample of a professional army of The Republic of Croatia (MESP05: $1.62 \pm$ 0.12 seconds, MESP10: $2.43 \pm 0.14$ seconds and
MES20M: $3.83 \pm 0.23$ seconds, Jukić et al., 2008), it can be seen that the referees are slightly slower than the players, but are faster than professional soldiers.

Based on the analysis of the obtained results in motor tests for evaluating agility and explosive power of sprint type, it can be concluded that the referees have adequately developed area of motor abilities which is necessary for effective game monitoring (officiating) - Table 3.

Given the use of representative sample of respondents in this research, the obtained results may even use as model parameters for the purpose of better control of the fitness - motor preparation of the referees.

TABLE 3

Descriptive statistical parameters of motoric tests

\begin{tabular}{lrrrrrr}
\hline \multicolumn{1}{c}{ Variables } & \multicolumn{1}{c}{$M$} & MIN & MAX & SD & SKEW & KURT \\
\hline MAG9OK (s) & 8.40 & 7.24 & 9.76 & .55 & -.15 & .19 \\
\hline MAGKUS (s) & 8.19 & 6.54 & 9.90 & .82 & .23 & -.19 \\
\hline MAGOSM (s) & 16.76 & 14.53 & 21.09 & .23 & 1.38 & 3.91 \\
\hline MAG4X5 (s) & 5.62 & 4.93 & 6.74 & .39 & .77 & 1.07 \\
\hline MESP05 (s) & 1.54 & 1.28 & 1.86 & .15 & -.13 & -.89 \\
\hline MESP10 (s) & 2.37 & 2.05 & 2.70 & .18 & -.10 & -.97 \\
\hline MES20M (s) & 3.78 & 3.37 & 4.21 & .24 & -.13 & -1.10 \\
\hline
\end{tabular}

Legend: $M$ - mean; $S D$ - standard deviation; $M I N$ - minimum value; $M A X$ - maximum value; MAG9OK - 93639 with a turn; MAGKUS - Side steps; MAGOSM - Eight with bending; MAG4X5 - 4 x 5 meters; MESP05 - Passage at 5 meters; MESP10 - Passage at 10 meters; MES20M - 20 meters run; (s) - seconds.

\section{TABLE 4}

T-test on independent samples - motoric tests

\begin{tabular}{lrrrrrr}
\hline Variables & $\begin{array}{c}M(26-32) \\
\text { Younger }\end{array}$ & $\begin{array}{c}M(33-46) \\
\text { Older }\end{array}$ & t-value & $d f$ & $p$ & $F$-ratio \\
\hline MAG9OK (s) & 8.09 & 8.73 & 3.89 & 29 & $\mathbf{. 0 0 0}$ & 1.610 \\
\hline MAGKUS (s) & 7.68 & 8.73 & 4.58 & 29 & $\mathbf{. 0 0 0}$ & 1.251 \\
\hline MAGOSM (s) & 15.98 & 17.59 & 4.73 & 29 & $\mathbf{. 0 0 0}$ & 3.499 \\
\hline MAG4X5 (s) & 5.44 & 5.83 & 3.17 & 29 & $\mathbf{. 0 0 3}$ & 1.414 \\
\hline MESP05 (s) & 1.47 & 1.62 & 3.14 & 29 & $\mathbf{. 0 0 3}$ & 1.114 \\
\hline MESP10 (s) & 2.27 & 2.48 & 3.83 & 29 & $\mathbf{. 0 0 0}$ & 1.295 \\
\hline MES20M (s) & 3.63 & 3.95 & 4.42 & 29 & $\mathbf{. 0 0 0}$ & 1.899 \\
\hline
\end{tabular}

Legend: MAG9OK - 93639 with a turn; MAGKUS - Side steps; MAGOSM - Eight with bending; MAG4X5 - 4 x 5 meters; MESP05 - Passage at 5 meters; MESP10 - Passage at 10 meters; MES20M - 20 meters run; (s) - secunds; $M$ - mean; $d f$ - degrees of freedom; $p$ - statistical significance. 
Based on the results in Table 4 it is evident that there are statistically significant differences in all tests for assessing the observed motor abilities between the two subsamples of respondents, or between the sample consisted of "younger" referees (26-32 years), and the other consisted of "older" referees (33-46 years). The results confirm the scientific fact that men's motor abilities gradually decrease with chronological age.

Determination of functional abilities of the referees was performed with a spiroergometry method using progressive load on a treadmill with a constant inclination of $1.5 \%$.

Based on comparison of the obtained results of absolute and relative maximal oxygen intake of the professional Croatian basketball players (Matković \& Matković, 2010) and the basketball referees, it can be concluded that the referees have lower values than the players' average.
Comparing the referees and the untrained population in Croatia, it is evident that their results are significantly better in average, and that the referees mostly fall into categories of very good or excellent aerobic capacities (Heimer et al., 2004).

The obtained values of heart rate and oxygen intake on anaerobic threshold with ventilation metabolic indicators, correspond to the values characteristic to sports activities dominated by aerobic energy processes, because the respondents were crossing the anaerobic ventilatory threshold at very high intensity load (Rupčić, 2010).

The average results of absolute $(4.59 \pm 0.48)$ and relative maximal oxygen intake (52.49 \pm 5.80$)$, the fact that the referees have crossed anaerobic ventilatory threshold in average at the value of $86.19 \pm$ $4.35 \%$ of maximal oxygen intake, or at the value of $90.97 \pm 3.07 \%$ of maximal heart rate, tell us about their well - developed aerobic endurance (Table 5).

TABLE 5

Descriptive statistical parameters of functional abilities

\begin{tabular}{lrrrrrr}
\hline \multicolumn{1}{c}{ Variables } & \multicolumn{1}{c}{$M$} & \multicolumn{1}{c}{$S D$} & $M I N$ & $M A X$ & $\max D$ & K-S p \\
\hline VO2max $(\mathrm{l} / \mathrm{min})$ & 4.59 & .48 & 3.77 & 5.60 & .0871 & .973 \\
\hline VO2max rel $(\mathrm{ml} / \mathrm{kg} / \mathrm{min})$ & 52.49 & 5.80 & 43.15 & 65.56 & .1217 & .748 \\
\hline relVO2ANP $(\mathrm{ml} / \mathrm{kg} / \mathrm{min})$ & 45.22 & 5.36 & 35.35 & 56.76 & .1191 & .771 \\
\hline \%VO2max ANP $(\%)$ & 86.19 & 4.35 & 75.43 & 94.84 & .1405 & .573 \\
\hline MVDmax $(1 / \mathrm{min})$ & 158.48 & 19.75 & 119.70 & 198.50 & .0912 & .959 \\
\hline VeEq $(\mathrm{l} / \mathrm{min})$ & 33.96 & 3.85 & 22.00 & 41.00 & .1685 & .342 \\
\hline VO2/HR $(\mathrm{ml} / \mathrm{beep})$ & 25.28 & 3.50 & 20.10 & 38.10 & .1418 & .561 \\
\hline V_max $(\mathrm{km} / \mathrm{h})$ & 15.41 & 1.08 & 13.50 & 17.00 & .1661 & .359 \\
\hline V_ANP $(\mathrm{km} / \mathrm{h})$ & 11.88 & 1.08 & 9.00 & 14.00 & .1365 & .610 \\
\hline Fsmax $(\mathrm{bpm})$ & 187.12 & 8.75 & 169.00 & 204.00 & .0853 & .978 \\
\hline FSANP $(\mathrm{bpm})$ & 170.16 & 8.75 & 152.00 & 184.00 & .1205 & .759 \\
\hline \%FSmaxANP $(\%)$ & 90.97 & 3.07 & 84.10 & 95.78 & .1435 & .545 \\
\hline
\end{tabular}

Legend: $M$ - mean; $S D$ - standard deviation; $M I N$ - minimum value; $M A X$ - maximum value; $\max D$-maximum distance between the theoretical cumulative relative frequency (nor$\mathrm{mal}$ ) and the relative cumulative empirical frequency (obtained by measurement); $K-S p$ - error of statistical inference; VO2max (1/min) - maximum oxygen intake; VO2max $\mathrm{rel}(\mathrm{ml} / \mathrm{kg} / \mathrm{min})$ - relative maximum oxygen intake; relVO2ANP $(\mathrm{ml} / \mathrm{kg} / \mathrm{min})$ relative oxygen intake at anaerobic threshold; \%VO2max ANP (\%) - oxygen intake at anaerobic threshold expressed as a percentage of maximal oxygen intake; MVDmax (1/ min) - maximal minute ventilation; VeEq $(1 / \mathrm{min})$ - ventilatory equivalent; VO2/HR (ml/beep) - maximal oxygen pulse; V_max $(\mathrm{km} / \mathrm{h})$ - maximal speed of treadmill; V_ANP (km/h) - speed of treadmill at anaerobic threshold; FSmax (bpm) - maximal heart rate; FSANP (bpm) - heart rate at anaerobic threshold; \%FmaxANP (\%) - heart rate at anaerobic threshold expressed as a percentage of maximal heart rate. 
Based on the results it can be concluded that the referees have a good developed aerobic capacity, similar to the professional basketball players (Castagna, Chaouachi, Rampinini, Chamari, \& Impellizzeri, 2009) as well as to the referees from other team sports (Casajus \& Castagna, 2007; Castagna \& D'Ottavio, 2001; Krustup \& Bangsbo, 2001).

Table 6 shows the results of $t$-test for independent samples between "younger" (26-32 years) and "older" (33-46 years) basketball referees in basic variables for estimating functional abilities (maximal oxygen intake; relative maximal oxygen intake, relative maximal oxygen intake at anaerobic threshold). Based on these results it is concluded that there is no statistically significant difference in the level of functional abilities of the basketball referees according to their chronological age.

Table 7 shows the results of $t$-test for independent samples between the two noted samples of respondents in variables: Quality of Officiating and Experience.

The results showed how the referees are statistically different in both variables. Based on the evaluation grades of controllers of officiating it is evident that "older" referees get a better average score (4.16) in the quality of officiating compared to "younger" basketball referees (3.95). Also, "older" referees have much more experience (10.60) in the officiating the highest level of competition in relation to "younger" referees (4.18).

\section{CONCLUSION}

Regarding the anthropological status, the basketball referees differ considering their chronological age only in variables (tests) for motor abilities evaluation, while there are no statistically significant differences in variables of morphological characteristics and functional abilities.

Therefore, it can be concluded that the basketball referees, who made this sample of respondents, have an optimal body composition, and well - developed aerobic capacity, and also the referees regardless of their older chronological age retain a high level of listed abilities.

The question is: Why do the basketball referees with weaker motor abilities, have better grades in average regarding the quality of officiating?

TABLE 6

T-test on independent samples - functional abilities

\begin{tabular}{lrrrrrr}
\hline \multirow{2}{*}{ Variables } & $\begin{array}{c}M(26-32) \\
\text { Younger }\end{array}$ & $\begin{array}{c}M(33-46) \\
\text { Older }\end{array}$ & $t$-value & $d f$ & $p$ & $F$-ratio \\
\hline VO2max $(\mathrm{l} / \mathrm{min})$ & 4.73 & 4.45 & -1.68 & 29 & .102 & 1.428 \\
\hline VO2max rel $(\mathrm{ml} / \mathrm{kg} / \mathrm{min})$ & 54.04 & 50.84 & -1.56 & 29 & .127 & 1.521 \\
\hline relVO2ANP $(\mathrm{ml} / \mathrm{kg} / \mathrm{min})$ & 46.54 & 43.82 & -1.43 & 29 & .163 & 2.106 \\
\hline
\end{tabular}

Legend: $\mathbf{M}$ - mean; $d f$ - degrees of freedom; $p$ - statistical significance.

TABLE 7

T-test on independent samples - Quality of Officiating and Experience

\begin{tabular}{lrrrrrr}
\hline \multicolumn{1}{c}{ Variables } & $\begin{array}{c}M(26-32) \\
\text { Younger }\end{array}$ & $\begin{array}{c}M(33-46) \\
\text { Older }\end{array}$ & t-value & $d f$ & $p$ & $F$-ratio \\
\hline Quality of Officiating (1-5) & 3.95 & 4.16 & 2.05 & 29 & .049 & 1.413 \\
\hline Experinece (years) & 4.18 & 10.60 & 4.51 & 29 & .000 & 4.803 \\
\hline
\end{tabular}

Legend: $M$ - mean; $d f$ - degrees of freedom; $p$ - statistical significance.

The answer is simple: the obtained results indicate the extreme complexity of the game of basketball which is directly related to complexity of the rules of basketball itself. All the referees who made the sample of respondents are physically well prepared and have met the high criteria of needed theoretical knowledge in the rules of basketball for officiating the highest national rank. However, in the end the experience in applying the gained knowledge makes them different in quality of officiating.

Once again it was showed that experience is an indispensable factor for successful officiating of the 
game of basketball. The results obtained confirmed the assumption how experienced referees, with the necessary theoretical knowledge "enriched" by the keen sense for the game, achieve better results in officiating a game, under the condition of good physical fitness. It is natural that the motor abilities of chronologically older basketball referees gradually decrease, but considering the complexity of the game, they make up for this deficiency with their gained officiating experience.

\section{REFERENCES}

Casajus, J. A., \& Castagna, C. (2007). Aerobic fitness and field test performance in elite Spanish soccer of referees different ages. Journal of Science and Medicine in Sport, 10(6), 382-389.

Castagna, C., \& D’Ottavio, S. (2001). Effect of maximal aerobic power on match performance in elite soccer referees. Journal of Strength and Conditioning Research, 15(4), 420-425.

Castagna, C., Chaouachi, A., Rampinini, E., Chamari, K., \& Impellizzeri, F. (2009). Aerobic and explosive power performance of elite Italian regional-level basketball players. Journal of Strength and Conditioning Research, 23(7), 1982-1987.

Heimer, S., Mišigoj-Duraković, M., Ružić, L., Matković, B., Prskalo, I., Beri, S., et al. (2004). Fitness level of adult economically active population in the republic of Croatia estimated by EUROFIT system. Collegium Antropologicum, 28(1), 223-233.

Jukić, I., Vučetić, V., Aračić, M., Bok, D., Dizdar, D., Sporiš, G., et al. (2008). Dijagnostika kondicijske pripreme vojnika (Diagnostics of physical fithess of soldiers). Zagreb: Kineziološki fakultet Sveučilišta u Zagrebu, Institut za istraživanje i razvoj obrambenih sustava.

Krustrup, P., \& Bangsbo, J. (2001). Physiological demands of top-class soccer refereeing in relation to physical capacity: effect of intense intermittent exercise training. Journal of Sports Sciences, 19, 881-891.

Received: October 18, 2010

Accepted: March 17, 2011
Lewis, C. E., Mc'Tigue, K. M., Burke, L. E., Poirier, P., Eckel, R. H., Howard, B. V., et al. (2009). Mortality, health outcomes, and Body Mass Index in the overweight range. A science advisory from the American Heart Association. Circulation, 119(25), 3263-3271.

Matković, Br., \& Matković, B. (2010). Funkcionalne i motoričke karakteristike košarkaša i košarkašica (Functional and motor characteristics of basketball players). In B. Matković (Ed.) Antropoloskea analiza košarkaške igre (pp. 107-121). Zagreb: Kineziološki fakultet, Hrvatski košarkaški savez.

Metikoš, D., Prot, F., Horvat, V., Kuleš, B., \& Hoffman, E. (1982). Bazične motoričke sposobnosti ispitanika natprosječnog motoričkog statusa (Basic motor skills of the above-motor status respondents). Kineziologija, 14(5), 21-62.

Mišigoj-Duraković, M., Heimer, S., \& Matković, Br. (1998). Morfološke i funkcionalne karakteristike studentske populacije Zagrebačkog sveučilišta (Morphological and functional characteristics of the student population of Zagreb University). Kineziologija, 30(2), 31-37.

Rupčić, T. (2010). Fiziološko opterećenje sudaca tijekom košarkaške utakmice (Physiological load of basketball referees during a game). Unpoblished doctoral dissertations, Sveučilište u Zagrebu, Kineziološki fakultet.

Rupčić, T., Matković, B., \& Knjaz, D. (2010). Antropološki profil košarkaških sudaca (Anthropological profile of basketball referees). Hrvatski Športskomedicinski Vjesnik, 25, 16-22.

Ružić, L., Heimer, S., Mišigoj-Duraković, M., \& Matković Br. (2003). Increased occupational physical activity does not improve physical fitness. Occupational \& Environmental Medicine, 60(12), 983-988.

Wilmore, J. H., Costill, D. L., \& Kenney, W. L. (2008). Body composition in sport. In J. Wilmore i D.L. Costill (Eds.), Physiology of Sport and Exercise (4th ed., pp. 318-327). Champaign, IL.: Human Kinetics.
Correspondence to: Tomislav Rupčić, PhD Kineziološki fakultet Horvaćanski zavoj 15 10000 Zagreb Croatia

Phone: 00385959125151

E-mail: tomislav.rupcic@kif.hr 